\title{
KONTRIBUSI AGROFORESTRI TERHADAP PENDAPATAN PETANI DI KELURAHAN SUMBER AGUNG KECAMATAN KEMILING KOTA BANDAR LAMPUNG
}

\section{CONTRIBUTION OF AGROFORESTRY FOR FARMERS INCOME IN SUMBER AGUNG VILLAGE KEMILING SUB-DISTRICT BANDAR LAMPUNG}

\author{
Oleh/By \\ Ulfa Nur Kholifah, Christine Wulandari, Trio Santoso dan Hari Kaskoyo \\ Jurusan Kehutanan Fakultas Pertanian Universitas Lampung \\ Jl. Soemantri Brojonegoro No. 1 Bandar Lampung \\ Email : un.kholifah@gmail.com \\ Phone : 085265926859
}

\begin{abstract}
ABSTRAK
Penduduk Sumber Agung menggantungkan hidupnya sebagai petani dengan sistem agroforestri di kawasan Tahura Wan Abdul Rachman. Sistem agroforestri yang diterapkan setiap penduduk memiliki karakteristik yang berbeda sehingga berpengaruh terhadap besar pendapatan keluarga. Penelitian ini memiliki tujuan untuk mengetahui besar kontribusi agroforestri terhadap pendapatan petani berdasarkan kondisi karakteristik pengusahaan agroforestrinya. Metode yang digunakan adalah proporsi pendapatan dan K Means Cluster sehingga diketahui informasi mengenai kondisi petani agroforestri dan karakteristik petani. Variabel yang diperhitungkan meliputi luas lahan, jumlah tanaman, jarak tanam, jarak kebun dan pendapatan agroforestri. Hasil penelitian menunjukkan kontribusi agroforestri mencapai rata-rata Rp10.660.989/kk/bulan dan jika dibandingkan dengan standar Upah Minimum Kota Bandar Lampung, nominal tersebut menunjukkan pendapatan petani tergolong tinggi. Petani dapat dibagi menjadi 6 kelompok dengan karakteristik yang berbeda. Kelompok dengan pendapatan tertinggi adalah kelompok 5 sedangkan kelompok dengan pendapatan terendah adalah kelompok 1 . Hal tersebut menunjukan pengelolaan lahan kelompok 5 adalah yang terbaik.
\end{abstract}

Kata kunci : Agroforestri, kontribusi pendapatan, K Means cluster, Tahura

\begin{abstract}
Sumber Agung community depend their life as a farmer with agroforestry management in Tahura Wan Abdul Rachman. Agroforestry system used has different characterics therefore have impact to farmers income. The purposes of the research is to analyze the amount of contribution farmers income based on condition of agroforestry characteristics cultivation. The research used revenue proportion method and $K$ Means cluster. The variables that become consideration namely total area, total plants, plant spacing, farm distance and agroforestry income. The result showed that the agroforestry contribution reach out $R p$ 10.660.989/hh/month and if compared with minimum income standart of Bandar Lampung City, its value show that the farmers income are relatively high. Farmers can be divided into six groups with different characteristics. The highest farmers income was fifth group and the lower farmers income was first group, it shows the best management is the fifth group.
\end{abstract}

Key words : Agroforestry, the contribution of income, K Means cluster, Tahura 


\section{PENDAHULUAN}

Hutan merupakan karunia dan amanah Tuhan Yang Maha Esa yang dianugerahkan kepada bangsa Indonesia dan merupakan kekayaan yang dikuasai oleh Negara serta memberikan manfaat serbaguna bagi umat manusia (Kemenhut, 1999). Hutan mempunyai banyak manfaat baik langsung maupun tidak langsung yang dapat diperoleh masyarakat. Banyaknya manfaat hutan tersebut maka diperlukan pengelolaan hutan yang baik agar berdampak terhadap kondisi ekonomi masyarakat. Contoh pengelolaan hutan di Indonesia adalah pola agroforestri yang bertujuan untuk pembangunan sektor kehutanan.

Salah satu pembangunan sektor kehutanan di Provinsi Lampung yaitu Hutan Pendidikan Konservasi Terpadu Taman Hutan Raya (Tahura) Wan Abdul Rachman (WAR). Hutan Pendidikan Konservasi Terpadu merupakan bagian dari Tahura WAR yang dibagi ke dalam tiga blok pengelolaan yaitu blok lindung, blok pemanfaatan dan blok lainnya. Pada blok lainnya pengelolaan hutan dilakukan dengan sistem pengelolaan agroforestri yang dilakukan oleh masyarakat sekitar hutan (Tiurmasari, 2016). Hutan Pendidikan Konservasi Terpadu Tahura WAR memiliki keberagaman hasil hutan yang mempengaruhi pendapatan rumah tangga petani. Keberagaman hasil hutan tersebut membentuk susunan komposisi tanaman berbeda-beda pada suatu luasan lahan sehingga memberikan pendapatan yang berbeda pula dari masing-masing komposisi tanaman. Hal tersebut mempengaruhi tingkat pendapatan petani agroforesrti. Oleh karena itu perlu dilakukan penelitian mengenai kontribusi agroforestri terhadap pendapatan petani yang bertujuan untuk mengetahui besar kontribusi yang diterima dari pola agroforestri serta mengelompokan petani berdasarkan karakteristik kondisi pengusahaan agroforestri.

\section{METODE PENELITIAN}

Penelitian dilaksanakan pada Bulan Februari sampai Mei 2016 di Kelurahan Sumber Agung Kecamatan Kemiling Kota Bandar Lampung. Populasi dalam penelitian ini adalah anggota gabungan kelompok tani yang berjumlah 496 anggota yang kemudian dihitung menggunakan rumus Slovin: Arikunto (2011) sehingga dihasilkan 41 responden. Alat yang digunakan dalam penelitian ini adalah kuisioner, kamera, dan dibantu dengan software statistika. Bahan yang digunakan adalah data primer dan sekunder. Data primer berupa data umum dari rumah tangga petani yang meliputi nama, umur, alamat, jenis kelamin, lama waktu pendidikan, pekerjaan pokok, pekerjaan sampingan, status perkawinan, jumlah anggota keluarga, jarak tanam, jenis tanaman, jarak rumah ke kebun dan luas lahan. Data primer diperoleh dari wawancara dengan petani agroforestri menggunakan bantuan kuisioner dan observasi lapang untuk mengamati kondisi lahan agroforestri. Data sekunder meliputi kondisi geografis lokasi penelitian, keadaan demografi, keadaan sosial ekonomi masyarakat, dan buku-buku literatur lain terkait pendapatan petani serta data-data lain yang berkaitan dengan penelitian yang didapat melalui studi literatur. Data primer yang digunakan adalah data satu tahun terakhir.

Metode yang digunakan untuk menghitung pendapatan yaitu pengurangan dari total penerimaan dan total pengeluaran. K Means cluster digunakan untuk meminimalkan variasi dalam satu kelompok dan memaksimalkan variasi antar kelompok. Data yang dikelompokkan adalah data luas lahan, jumlah jenis tanaman, jarak tanam, jarak rumah ke kebun dan pendapatan agroforestri. Data yang telah didapat distandarkan terlebih dahulu lalu dianalisis untuk menentukan kelompok. Penentuan jumlah kelompok ditentukan berdasarkan iterasi atau pengulangan yang terjadi. Pengelompokan dilakukan untuk mengetahui perbedaan kondisi pengusahaan agroforestri dari masing-masing kelompok. 


\section{HASIL DAN PEMBAHASAN}

\section{A. Kontribusi Agroforestri terhadap Pendapatan Petani}

Kontribusi yang bersumber dari agroforestri adalah perkebunan, pertanian dan peternakan. Data pendapatan responden petani agroforestri disajikan pada tabel 1.

Tabel 1. Kontribusi Pendapatan Seluruh Responden Petani Agroforestri.

\begin{tabular}{lrcc}
\hline Sumber Pendapatan & $\begin{array}{c}\text { Pendapatan } \\
\text { Petani }(\mathbf{R p} / \mathbf{t h})\end{array}$ & $\begin{array}{c}\text { Rata-rata } \\
\text { Pendapatan }(\mathbf{R p} / \mathbf{k k} / \mathbf{t h})\end{array}$ & $\begin{array}{c}\text { Kontribusi terhadap } \\
\text { pendapatan total }(\boldsymbol{\%})\end{array}$ \\
\hline Agroforestri & $\mathbf{5 . 2 4 5 . 2 0 6 . 7 0 0}$ & $\mathbf{1 2 7 . 9 3 1 . 8 7 1}$ & $\mathbf{9 8 . 4 7}$ \\
Perkebunan & 4.228 .716 .700 & 103.139 .432 & 79.38 \\
Pertanian & 764.340 .000 & 18.642 .439 & 14.35 \\
Peternakan & 252.150 .000 & 6.150 .000 & 4.73 \\
& & & \\
Non Agroforestri & $\mathbf{8 1 . 7 0 0 . 0 0 0}$ & $\mathbf{1 . 9 9 2 . 6 8 3}$ & $\mathbf{1 . 5 3}$ \\
PNS & 36.000 .000 & 878.049 & 0.68 \\
Pedagang & 13.200 .000 & 321.951 & 0.25 \\
Jamur & 32.500 .000 & 792.683 & 0.61 \\
& & & $\mathbf{1 0 0 . 0 0}$ \\
Total & $\mathbf{5 . 3 2 6 . 9 0 6 . 7 0 0}$ & $\mathbf{1 2 9 . 9 2 4 . 5 5 4}$ & \\
\hline
\end{tabular}

Sumber: hasil penelitian tahun 2016.

Berdasarkan Tabel 1, agroforestri memberikan kontribusi sebesar 98,47\% dengan luas lahan yang dimiliki responden adalah 0,25 ha sampai dengan 4,5 ha atau rata-rata luas lahan yaitu 1,25 ha. Pendapatan dari non agroforestri memberikan kontribusi 1,53\%. Pendapatan bersumber dari agroforestri memberikan pemasukan yang lebih besar dibandingkan dengan pendapatan yang bersumber dari non agroforestri. Petani di Sumber Agung sangat bergantung pada lahan agroforestri dalam memenuhi kebutuhan hidup karena lahan agroforestri menjadi sumber penghasilan utama dan seluruh penduduk berprofesi sebagai petani agroforestri. Menurut Mayrowani dan Ashari (2011) agroforestri dikembangkan untuk meningkatkan kesejahteraan masyarakat, diutamakan dapat membantu mengoptimalkan hasil suatu penggunaan lahan secara berkelanjutan guna menjamin dan memperbaiki kebutuhan hidup masyarakat dan dapat meningkatkan daya dukung manusia, khususnya di daerah pedesaan. Selain hal tersebut, yang menyebabkan pendapatan non agroforestri rendah adalah karena hanya terdapat $17 \%$ petani yang memiliki pendapatan yang bersumber dari non agroforestri. Di Sumber Agung mata pencaharian dari non agroforestri yaitu PNS, pedagang dan budidaya jamur.

Berdasarkan Keputusan Gubernur Lampung Nomor: G/615/III.05/HK/2015 tentang penetapan Upah Minimum Kota (UMK) Bandar Lampung tahun 2016, besarnya UMK Bandar Lampung adalah sebesar Rp1.870.000/bulan. Berdasarkan besaran rata-rata pendapatan yang diperoleh responden yaitu Rp10.660.989 kk/bulan dan dibandingkan dengan UMK Bandar Lampung, dapat disimpulkan bahwa pendapatan tersebut tergolong tinggi dan sudah dapat mencukupi kebutuhan petani.

\section{Pendapatan Petani Agroforestri dari Perkebunan}

Agroforestri dari lahan perkebunan memberikan kontribusi yang lebih besar yaitu 79,38\%. Hal tersebut terjadi karena rata-rata petani di Sumber Agung memiliki komposisi tanaman yang variatif yaitu 16 jenis tanaman. Berbeda dengan studi kasus 
di Desa Sukoharjo Kabupaten Pringsewu yang memiliki kontribusi agroforestri lebih rendah yaitu 88,31\% dengan hanya memiliki 11 jenis komoditi (Olivi, 2014).

Pengembangan lahan agroforestri dilakukan dengan mengkombinasikan berbagai jenis tanaman kehutanan dengan tanaman perkebunan. Tanaman karet merupakan komoditi yang memberikan kontribusi paling besar yaitu 59,17\%. Karet merupakan tanaman dominan dengan variasi jumlah tanaman antar responden yaitu 10 pohon/kebun sampai dengan 2.000 pohon/kebun. Meskipun saat ini harga getah karet terbilang murah yaitu Rp 4.000/kg dibandingkan dengan harga sebelumnya yaitu Rp $12.000 / \mathrm{kg}$, petani tetap mengandalkan karet sebagai komoditi yang menghasilkan karena masih memberikan keuntungan yang besar. Petani agroforestri di Sumber Agung yang menanami lahan agroforestrinya dengan komoditi karet adalah sebanyak $78,05 \%$.

Menyikapi harga karet yang turun, para petani di Sumber Agung lebih memperhatikan teknik pemanenannya, pemanenan karet seharusnya dilakukan pada saat karet berumur diatas tiga tahun. Sebelumnya komoditi karet sudah dipanen pada umur dua tahun sehingga tingkat produksi getah yang dihasilkan masih sedikit, berbeda dengan saat ini komoditi karet dipanen pada saat umur produktif yaitu tiga tahun. Selain itu kedalaman sadapan yang dilakukan terkadang mengenai bagian kayu karet yang membuat pengembalian kulit batang menjadi tidak sempurna seperti semula (cacat batang). Seperti dalam penelitian Pusari dan Haryanti (2014), batang karet yang matang sadap memiliki usia 3,5 sampai 5 tahun dan penyadapan dilakukan dengan ketebalan $2 \mathrm{~mm}$ dan tidak mengenai kambium, serta penyadapan membentuk sudut kemiringan $45^{\circ} \mathrm{C}$.

Berdasarkan Tabel 2, komoditi kopi menjadi komoditi yang memberikan kontribusi terbesar kedua setelah karet yaitu 9,56\%. Petani agroforestri di Sumber Agung yang menanami lahan agroforestrinya dengan komoditi kopi adalah sebanyak 56,10\%. Variasi pendapatan kopi antar responden yaitu berkisar Rp 315.000/tahun sampai dengan Rp 157.500.000/tahun. Frekuensi pemanenan kopi di Sumber Agung sebanyak dua kali dalam setahun. Panen pertama merupakan panen raya dan panen kedua adalah panen selang. Panen raya dilakukan di awal musim panen dan panen selang dilakukan sebulan setelah panen raya. Setelah dilakukan pemanenan, biji-biji kopi dijemur oleh petani. Setelah biji tersebut mengering langsung dijual ke pengepul yang berada di Sumber Agung untuk diolah menjadi bubuk kopi.

Tabel 2. Pendapatan total responden yang bersumber dari perkebunan

\begin{tabular}{|c|c|c|c|}
\hline $\begin{array}{c}\text { Jenis } \\
\text { Tanaman }\end{array}$ & $\begin{array}{c}\text { Total } \\
\begin{array}{c}\text { Pendapatan/tahun } \\
(\mathbf{R p} / \text { th })\end{array} \\
\end{array}$ & $\begin{array}{c}\text { Rata-rata pendapatan } \\
(\mathrm{Rp} / \mathrm{kk} / \mathrm{th})\end{array}$ & Persentase (\%) \\
\hline Karet & 2.502 .128 .000 & 61.027 .512 & 59,17 \\
\hline Kopi & 404.410 .000 & 9.863 .659 & 9,56 \\
\hline Durian & 356.000 .000 & 8.682 .927 & 8,42 \\
\hline Total & 3.260 .538 .000 & 79.574 .098 & 77,15 \\
\hline
\end{tabular}

Sumber: hasil penelitian tahun 2016.

Durian menjadi komoditi yang sangat dinantikan musimnya karena memberikan kontribusi penghasilan ketiga terbesar, terlebih saat ini Sumber Agung sedang dalam proses menjadi Desa Wisata Durian yaitu sebagai pusat penjualan komoditi durian di Tahura WAR. Seluruh petani agroforestri di Sumber Agung memiliki tanaman durian di lahan agroforestrinya. Variasi pendapatan durian antar 
responden yaitu berkisar Rp 850.000/tahun sampai dengan Rp 51.212.500/tahun. Variasi pendapatan tersebut terjadi karena jumlah tanaman antar responden berbedabeda yaitu 2 tanaman/ha sampai dengan 80 tanaman/ha. Pemanenan durian dilakukan sekali dalam setahun karena durian merupakan tanaman yang berbuah tahunan.

Petani di Sumber Agung memasarkan seluruh hasil hutan ke pengepul. Pengepul merupakan pedagang yang berkembang secara tradisional di indonesia dalam membeli komoditas dari petani sebagai pengumpul sekaligus pemasar dengan harga yang cukup murah bahkan sangat jauh dibawah harga pasaran. Terkadang petani hanya menunggu pengepul datang menghampiri ke rumah petani dengan alasan tidak ingin repot dan mengurangi biaya transportasi. Di Sumber Agung terdapat juga sistem borongan biasanya berlaku untuk durian, petai dan lain-lain. Sistem borongan yaitu konsumen atau pengepul mengambil sendiri di pohon. Hasil komoditi yang dijual ke pengepul memiliki harga yang relatif lebih murah dibandingkan dengan yang dijual langsung kepada konsumen, hal tersebut mempengaruhi pendapatan yang diterima oleh petani.

\section{Pendapatan Petani Agroforestri dari Petanian}

Pendapatan agroforestri dari pertanian memberikan kontribusi 14,35\%. Tanaman pertanian yang ada di Sumber Agung hanya jenis cabai. Berdasarkan hasil diskusi dengan responden penelitian sebanyak 80,49\% memiliki tanaman cabai. Bibit cabai yang digunakan petani adalah hasil semai dari pembelian bibit cabai di toko pertanian, namun ada juga petani yang menyemai benih cabai dari sisa pemakaian rumah tangga. Tanaman cabai menjadi tanaman selang diantara komoditi perkebunan sehingga pola tanamnya mengikuti jarak tanam komoditi perkebunan.

Pemeliharaan lahan yang dilakukan di Sumber Agung adalah pendangiran, penyiangan dan pemupukan. Pendangiran dilakukan untuk menggemburkan tanah yang akan ditanami. Pendangiran dilakukan secara sederhana menggunakan cangkul. Penyiangan dilakukan dengan membersihkan gulma agar tidak mengurangi produktifitas tanaman. Kegiatan pemupukan dilakukan setiap tiga hari sekali menggunakan pupuk kandang (kotoran ternak). Pemeliharaan tanaman dilakukan untuk meningkatkan produktivitas yang berpengaruh terhadap pendapatan yang diterima petani. Tanaman yang tumbuh dengan baik cenderung memberikan hasil yang optimal dibandingkan dengan tanaman yang tidak tumbuh dengan baik.

Kegiatan pemanenan dilakukan oleh tenaga kerja dalam keluarga. Cabai yang sudah dipanen akan langsung di jual ke pengepul karena pertimbangan kualitas cabai. Semakin lama cabai berada dalam tumpukan maka kualitas cabai akan semakin menurun, cabai akan mengalami pembusukan yang lebih cepat antara lain karena pengaruh suhu. Kualitas cabai yang menurun tentunya berdampak pada pendapatan yang diterima petani.

\section{Pendapatan Petani Agroforestri dari Peternakan}

Pendapatan dari peternakan memberikan kontribusi 4,73\%. Berdasarkan hasil diskusi dengan responden, sebanyak $82,93 \%$ memiliki hewan ternak. Ternak yang dimiliki petani hanya dua jenis yaitu kambing dan sapi, untuk banyaknya kambing yang dimiliki petani minimal satu ekor dan maksimal 5 ekor kambing, sedangkan ternak sapi yang dimiliki petani hanya memiliki maksimal 1satu ekor sapi. Petani tidak memiliki ternak dalam jumlah besar karena petani takut kesusahan dalam mengurusnya. Kandang ternak diletakkan tidak jauh dari rumah dan besarnya disesuaikan dengan banyaknya ternak yang dimiliki oleh masing-masing petani. 
Pakan ternak tersebut berasal dari lahan kebun seperti rumput dan daun nangka. Petani setiap hari mencari rumput ke ladang untuk mencari pakan ternak sekaligus mengontrol kondisi ladang. Petani menjual ternaknya dengan membuat pondokan kecil di pinggir jalan. Sistem penjualan ternak dilakukan dengan menggabungkan ternak-ternak yang dimiliki petani di satu tempat. Tanda kepemilikan ternak menggunakan cat berwarna atau kalung tambang berwarna agar ternak tidak tertukar. Kontribusi dari peternakan terbilang sangat kecil karena ternak dijual hanya pada musim-musim tertentu yaitu menjelang hari raya Idul Adha. Pendapatan yang didapatkan menjadi lebih sedikit dibandingkan pendapatan dari perkebunan dan pertanian.

\section{Pendapatan Non Agroforestri}

Pendapatan non agroforestri merupakan pendapatan yang diluar kegiatan perkebunan, pertanian dan peternakan. Di Sumber Agung hanya 0,68\% atau satu orang yang memiliki pekerjaan tetap sebagai PNS, dengan penghasilan pertahun sebesar Rp 36.000.000/kk/tahun.

Berdasarkan hasil diskusi dengan responden, sebanyak 9,75\% petani membudidayakan jamur tiram. Bibit dan media tumbuh jamur (beklok) diperoleh dari pabrik budidaya jamur milik seorang pengusaha tionghoa yang berada di Sumber Agung juga. Budidaya jamur tiram dilakukan oleh petani selain untuk menambah pendapatan yaitu untuk mengisi lahan pekarangan rumah yang lapang. Bisnis budidaya jamur tergolong menguntungkan karena petani dapat memanen jamur setiap hari sebanyak $500 \mathrm{~kg} / 1000$ beklok selama satu bulan, setelah satu bulan beklok jamur kurang produktif karena bibit jamur di dalam beklok sudah mulai habis, tetapi tetap menghasilkan namun dalam jumlah kecil. Setelah tiga bulan baru dilakukan penggantian beklok jamur yang baru. Biaya produksi yang dikeluarkan tidak begitu banyak yaitu Rp 2.500.000/1000 beklok sehingga petani yang memiliki pekarangan rumah yang luas memilih membudidayakan jamur tiram. Usaha budidaya jamur ini memberikan kontribusi sebesar Rp 32.500.000/kk/tahun.

Pendapatan yang bersumber dari non agroforestri antara lain perdagangan. Usaha dagang yang dimaksud yaitu sebagai pedagang sembako, pengepul dan penjualan gula aren. Usaha ini memberikan kontribusi sebesar 0,25\%. Petani agroforestri yang menjadi pedagang adalah sebanyak $4,87 \%$.

\section{B. Karakteristik dan Pengelompokan Petani Agroforestri.}

Penentuan jumlah kelompok petani agroforestri yang dipilih, ditentukan berdasarkan banyak sedikitnya iterasi yang terjadi. Semakin kecil jumlah iterasi maka semakin baik, begitu pula sebaliknya (Merliana dkk, 2014). Iterasi merupakan pengulangan model algoritma $K$ Means cluster yang dilakukan hingga data yang dihasilkan signifikan. Berdasarkan hasil analisis yang telah dilakukan, kelompok 4 menghasilkan jumlah iterasi sebanyak empat, kelompok 5 menghasilkan jumlah iterasi sebanyak empat dan kelompok 6 menghasilkan jumlah iterasi sebanyak tiga. Iterasi paling sedikit terjadi pada kelompok 6 sehingga dipilih kelompok 6 sebagai model pengelompokan karakteristik pengusahaan agroforestri di Sumber Agung. Pengelompokan petani agroforestri kedalam 6 kelompok memiliki variasi karakteristik seperti pada Tabel 3. 
Tabel 3. Variasi rata-rata karakteristik pengelompokan petani agroforestri.

\begin{tabular}{ccccccc}
\hline \multirow{2}{*}{ Kelompok } & $\begin{array}{c}\text { Jumlah } \\
\text { Anggota }\end{array}$ & $\begin{array}{c}\text { Luas } \\
\text { Lahan } \\
\text { (ha) }\end{array}$ & $\begin{array}{c}\text { Jumlah Jenis } \\
\text { Tanaman } \\
\text { (Jenis/ha) }\end{array}$ & $\begin{array}{c}\text { Jarak } \\
\text { Tanam } \\
(\mathbf{m})\end{array}$ & $\begin{array}{c}\text { Jarak Rumah } \\
\text { ke Kebun } \\
(\mathbf{k m})\end{array}$ & $\begin{array}{c}\text { Pendapatan } \\
\text { Agroforestri } \\
\text { (Rp/kk/th) }\end{array}$ \\
\hline 1 & 15 & 1,23 & 8 & 5,25 & 2,37 & 129.924 .554 \\
2 & 1 & 1,25 & 10 & 5,12 & 1,50 & 178.869 .500 \\
3 & 11 & 1,18 & 8 & 5,22 & 2,39 & 150.058 .309 \\
4 & 8 & 1,82 & 9 & 5,16 & 2,50 & 136.200 .150 \\
5 & 1 & 4,00 & 10 & 5,10 & 2,50 & 895.234 .000 \\
6 & 5 & 1,43 & 8 & 5,18 & 2,38 & 134.138 .767 \\
\hline
\end{tabular}

Sumber : hasil penelitian tahun 2016.

Tabel 3 menunjukkan di Sumber Agung didominasi oleh petani kelompok 1 dengan pendapatan terendah yaitu Rp 129.924.554/kk/tahun. Pendapatan tersebut dipengaruhi banyak faktor diantaranya luas lahan karena semakin besar luas lahan yang dikelola petani maka semakin banyak pula jenis komoditi yang dapat ditanam terutama komoditi yang memberikan pendapatan. Luas lahan di kelompok 1 tergolong kecil yaitu 1,23/kk/ha, selain itu jenis tanaman tergolong sedikit, hanya 8 jenis saja. Kelompok 5 menjadi kelompok dengan pendapatan tertinggi yaitu Rp 895.234.000/kk/tahun, hal tersebut disebabkan selain memiliki lahan yang luas petani tersebut juga memaksimalkan pemanfaatan lahan yang dimiliki berupa menanam lahan dengan 10 jenis komoditi. Komoditi terbanyak adalah kopi sebanyak 5.000 batang dan komoditi karet sebanyak 2.000 batang.

Luas lahan terbesar adalah kelompok 5 yaitu 4 ha dan luas lahan terkecil adalah kelompok 3 yaitu 1,18 ha. Luas lahan mempengaruhi besar kecilnya pendapatan, seperti yang dinyatakan oleh Sitepu (2014), semakin luas lahan yang dimiliki maka semakin banyak pula jenis komoditi agroforestri yang dapat ditanam dilahan tersebut. Dengan demikian semakin besar pula pendapatan yang diterima petani.

Upaya pengawasan faktor produksi akan semakin baik jika luas lahan semakin sempit namun hal tersebut cenderung menghasilkan usaha yang tidak efisien karena produktivitas tanaman pada lahan yang terlalu sempit akan berkurang dibandingkan produktivitas pada lahan yang lebih luas (Phahlevi, 2013). Luas lahan diduga berpengaruh terhadap banyak sedikitnya tenaga kerja yang dibutuhkan, di Sumber Agung tenaga kerja yang digunakan merupakan tenaga kerja dalam keluarga, maka jumlah pekerja menjadi tidak tetap, sehingga jumlah tenaga kerja dalam penelitian ini tidak diperhitungkan.

Kelompok dengan jenis tanaman terbanyak adalah kelompok 2 dan 5 sebanyak 10 jenis/ha, hal itu menjadi salah satu penyebab kedua kelompok tersebut menjadi kelompok dengan pendapatan terbesar. Sedangkan kelompok dengan jenis tanaman paling sedikit adalah kelompok 3 dan 6 yang hanya memiliki 8 jenis tanaman/ha. Jenis tanaman dalam penerapannya diperlukan dukungan pengembangan pengetahuan karena hal tersebut mempengaruhi pola pikir petani dalam pemanfaatan lahan. Rata-rata petani di Sumber Agung memilih jenis komoditi dengan mempertimbangan teknis dan ekonomis yang memperhitungkan pengelolaan, produksi, keuntungan dan kerugian. Hal tersebut selaras dengan penelitian Wulandari dkk (2014), yang menyatakan bahwa petani cenderung lebih memilih jenis tanaman untuk lahan agroforestrinya adalah yang bernilai ekonomi.

Kelompok yang memiliki jarak tanam terdekat adalah kelompok 5 dan kelompok dengan jarak tanam terjauh adalah kelompok 1. Jarak tanam memberikan pengaruh terhadap produktivitas komoditi, baik diameter atau produksi hasil hutan lainnya. Pengaturan jarak tanam berpengaruh terhadap besarnya intensitas cahaya dan ketersediaan unsur hara yang dibutuhkan tanaman. Hal tersebut berdampak pada pendapatan yang 
diterima petani karena semakin optimal produktivitas komoditi maka hasil yang diberikan semakin besar. Oleh karena itu pengaturan jarak tanam sangat penting diperhatikan.

Petani agroforestri di Sumber Agung memiliki jarak dari rumah ke kebun bervariasi. Jarak tempuh terdekat adalah kelompok 2 yaitu $1,50 \mathrm{~km}$ dan jarak tempuh terjauh adalah kelompok 5 yaitu 2,50 km. Jauh dekat jarak kebun mempengaruhi sering tidaknya petani mengolah lahan yang dimiliki yang berdampak pula pada pendapatan petani. Seperti yang dinyatakan oleh Diniyati dan Awang (2010), bahwa semakin jauh jarak rumah petani dari lahannya, akan semakin jarang dikunjungi. Sehingga lahan tersebut cenderung ditanami dengan jenis yang kurang variatif. Sebaliknya, untuk lahan yang berdekatan dengan rumah akan cenderung mudah mengalami perubahan jenis tanaman yang dipilih. Faktor ini tentu akan sangat mempengaruhi pendapatan petani yang diperoleh dari produktivitas yang dihasilkan dari jenis-jenis tanaman yang dihasilkan.

Pengelompok petani agroforestri memberikan informasi karakteristik pengusahaan agroforestri yang bertujuan untuk meminimalkan variasi dalam satu kelompok dan memaksimalkan variasi antar kelompok sehingga dapat membantu memudahkan stakeholder dalam pengalokasian bantuan agar tepat sasaran berdasarkan skala prioritas yang berdampak pada pengelolaan agroforestri yang lebih baik dan berkelanjutan.

\section{KESIMPULAN}

Kontribusi agroforestri terhadap pendapatan petani di Kelurahan Sumber Agung sebesar 98,47\%. Berdasarkan besaran pendapatan yang diperoleh responden dan dibandingkan dengan Upah Minimum Kabupaten (UMK) Bandar Lampung dapat disimpulkan bahwa pendapatan tersebut tergolong tinggi dan sudah dapat memenuhi kebutuhan petani. Petani di Kelurahan Sumber Agung berdasarkan pendapatan yang diterima dapat dikelompokkan menjadi 6 (enam) kelompok. Kelompok dengan rata-rata pendapatan agroforestri tertinggi yaitu kelompok 5 (lima) dan kelompok dengan rata-rata pendapatan agroforestri terendah adalah kelompok 1 (satu). Hal tersebut menunjukan tingkat pengelolaan pada kelompok 5 lebih baik dibanding kelompok 1 .

\section{DAFTAR PUSTAKA}

Arikunto, S. 2011. Manajemen Penelitian. Buku. Rineka Cipta. Jakarta. 370 p.

Awang, S.A dan Diniyati, D. 2010. Kebijakan penentuan bentuk insentif pengembangan hutan rakyat di Wilayah Gunung Sawal, Ciamis dengan metode AHP. Jurnal Analisis Kebijkaan Kehutanan. 7 (2):129-143.

Kemenhut. 1999. Undang-undang No. 41 Tahun 1999 tentang Kehutanan. Lembaran Negara RI Tahun 1999, No. 62. Sekretariat Negara. Jakarta.

Mayrowani, H dan Ashari. 2011. Pengembangan agroforestri untuk mendukung ketahanan pangan dan pemberdayaan petani sekitar hutan. Forum Penelitian Agro Ekonomi. 29 (2):83-98.

Merliana, N., Ernawati dan Santoso, A. 2014. Analisa penentuan jumlah cluster terbaik pada metode k-means clustering. Prosiding Seminar Nasional Multi Disiplin Ilmu Unisbank. $6 \mathrm{p}$. 
Olivi, R. 2014. Kontribusi agroforestri terhadap pendapatan petani di Desa Sukoharjo 1 Kecamatan Sukoharjo Kabupaten Pringsewu. Jurnal Sylva Lestari. 3 (2):1-12.

Pemerintah Provinsi Lampung. 2015. Peraturan Gubernur Provinsi Lampung No.G/615 tentang Penetapan Upah Minimum Kota (UMK) Bandar Lampung 2016. Sekertariat Daerah. Bandar Lampung.

Phahlevi, R. 2013. Faktor-faktor yang mempengaruhi pendapatan petani padi sawah di Kota Padang Panjang. Jurnal Ekonomi Pembangunan. 1 (2):1-22.

Pusari, D dan Haryanti, S. 2014. Pemanenan getah karet (Hevea brasiliensis Muell. Arg) dan penentuan kadar karet kering (KKK) dengan variasi temperatur pengovenan di PT. Djambi Waras Jujuhan Kabupaten bungo, Jambi. Jurnal Anatomi dan Fisiologi. 22 (2):64-74.

Tiurmasari, S. 2016. Analisis vegetasi dan tingkat kesejahteraan masyarakat pengelola agroforestri di Desa Sumber Agung Kecamatan Kemiling Kota Bandar Lampung. Skripsi. Universitas Lampung. Bandar Lampung. 49 p.

Wulandari, C., P. Budiono, S.B. Yuwono, dan S. Herwanti. 2014. Adoption of agro-forestry patterns and crop system around Register 19 Forest Park, Lampung Province, Indonesia. Jurnal Manajemen Hutan Tropika. 20 (2): 86-93. 